\title{
KOHESI GRAMATIKAL KONJUNGSI WACANA KOLOM "HIKMAH" SURAT KABAR REPUBLIKA
}

\author{
Endang Wiyanti \\ Universitas Indraprasta PGRI \\ E-mail: endang_rahmadhani@yahoo.com
}

\begin{abstract}
The purpose of this study is to describe the empirical data of grammatical cohesion discourse connectives Republika newspaper column "Hikmah" and to see the cohesiveness of discourse Republika newspaper column "Hikmah" from the aspect of grammatical cohesion conjunctions.The research method is a method of content analysis studies. Data in the form of twenty-five titles discourse "Hikmah" column in August 2015 which was published months of randomly selected 286 titles from the discourse. Data collection techniques used in this research is to study the literature, namely by conducting research and data collection to the Center of the Republika daily data on 13 April 2016. Steps of data analysis was done by determining the text, decontextualization, determine the couple close together, writing partner, an analysis of each pair, recapitulation, and describe the results of the analysis. The study was conducted on March 20thto June 29th 2016.The results showed that a sentence of 124 couples studied, 44 or 35,5\% of couples discourse sentence using conjunctions between sentences "Hikmah" column with details of 16 or $12,9 \%$ of couples using conjunctions between sentences stating an additive relationship, 10 or $8,1 \%$ using adversative conjunctions that express relationships, 9 or 7,3\% using conjunctions expressing causal relationships, and 9 or 7,3\% using conjunctions which express temporal relations.
\end{abstract}

Keywords: grammatical cohesion, conjunctions, discourse

\begin{abstract}
ABSTRAK
Tujuan penelitian ini adalah untuk mendeskripsikan data empiris kohesi gramatikal konjungsi wacana kolom "Hikmah" surat kabar Republika dan untuk melihat kekohesifan wacana kolom "Hikmah" surat kabar Republika dari aspek kohesi gramatikal konjungsi. Metode penelitian adalah metode studi analisis isi. Data dalam bentuk dua puluh lima judul wacana kolom "Hikmah" yang terbit pada bulan Agustus 2015 dipilih secara acak dari 286 judul wacana. Teknik pengumpulan data yang digunakan dalam penelitian ini adalah dengan studi pustaka, yaitu dengan melakukan penelitian dan pengumpulan data ke Pusat data harian umum Republika pada 13 April 2016. Langkah-langkah analisis data dilakukan dengan menentukan teks, dekontekstualisasi, menentukan pasangan berdekatan, menulis pasangan, analisis masing-masing pasangan, rekapitulasi, dan mendeskripsikan hasil analisis. Penelitian dilakukan pada 20 Mare t--29 Juni 2016.Hasil penelitian menunjukkan bahwa dari 124 pasangan kalimat yang diteliti, 44 atau 35,5\% pasangan kalimat wacana kolom "Hikmah" menggunakan konjungsi antarkalimat dengan rincian 16 atau 12,9\% pasangan kalimat menggunakan konjungsi antarkalimat yang menyatakan hubungan aditif, 10 atau 8,1\% menggunakan konjungsi yang menyatakan hubungan adversatif, 9 atau 7,3\% menggunakan konjungsi mengekspresikan hubungan kausal, dan 9 atau 7,3\% menggunakan konjungsi yang menyatakan hubungan temporal.
\end{abstract}

Kata kunci: kohesi gramatikal, konjungsi, wacana 


\section{PENDAHULUAN}

Pembelajaran bahasa Indonesia secara umum bertujuan agar siswa mampu berbahasa Indonesia secara wajar dalam mengungkapkan pikiran dan sikapnya sesuai dengan situasi. Tolok ukur kemampuan berbahasa ini tidak hanya berupa kebahasaan, tetapi juga meliputi unsur nonkebahasaan, seperti tempat, waktu, adat, mimik, dan hubungan antarpembaca. Siswa belajar bahasa Indonesia bukan berarti siswa senantiasa dituntut berbahasa Indonesia secara kaku dan baku kapan dan di mana pun berada, melainkan disesuaikan dengan situasi dan kondisi. Mengingat pembelajaran bahasa Indonesia difokuskan pada aspek penggunaan bahasa baik lisan maupun tulisan, aspek pemahaman dan kebahasaan pun tercakup di dalamnya. Artinya, kegiatan belajar mengajar bahasa Indonesia memadukan ketiga aspek tersebut dengan tidak mengurangi ciri masing-masing.

Aspektersebutmeliputilafal, ejaan, tanda baca, kosa kata, tata bahasa, paragraf, dan wacana. Semua itu selalu ditemukan dalam keseluruhan keterampilan berbahasa yaitu menyimak, berbicara, membaca, dan menulis.

$$
\text { Tidakterlepas pada }
$$

tujuanpembelajaran,

bahanpembelajaranmerupakanunsurterpent ingdalampembelajaran. Bahan pembelajaran ini dapat diperoleh dari berbagai sumber: buku teks, narasumber (orang), pengalaman siswa sendiri, majalah, tabloid, surat kabar, dan lainlain.Sebagaibahanpembelajaran, suratkabarmempunyaisifat yang unik. Walaupunberupatekstertulis, suratkabardapatdijadikanbahanpembelajara naspekmembaca, berbicara, mendengarkan, dan utamanyaaspekmenulis secara terpadu. Surat kabar, sebagaisalahsatubahanpembelajaranmemua tinformasi yang aktual, iklan, dan opini. Pendidikdapatmenentukanbagian mana dan darisudutpandangapasuratkabarakandijadik anbahanpembelajaran yang sesuaidenganbahasanmateri. 
Salahsatusuratkabar yang terbit di Jakarta

dan dapatdijadikansumberbahanpembelajarana dalahharianumumRepublika yang memuatperistiwaterkinidaridalam dan luarnegeri. Sepertihalnyasuratkabar pada umumnya, penyajianinformasiharianumumRepublikad isajikandalambentukkolom-kolom. Yang membedakanRepublikadengan media cetaklainnyaialahdimuatnyakolom"Hikma h". Sesuaidengannamanya, kolom“Hikmah”menyajikanbahasanaktualt erkaitdenganpermasalahan yang sedangmenjadisorotanmasyarakat, darisusutpandang para penuliskolomtersebut.

Halinihampirmenyerupaidengantajuk.

Namun, yang membedakandengantajukadalahtajukditulis olehredaksisuratkabar yang bersangkutansedangkan“Hikmah"ditulisole hpenulislepas yang berbeda-beda pada setiapepisodenya.
Sebagaibahanpembelajaranbahasa, kolom"Hikmah"dapatdijadikanbahanpemb ahasanmateriwacanaopini.

Untukituperludiadakanpenelitianterhadapk olom"Hikmah"darisudutwacana.

Salahsatuunsurwacana yang perluditelitidarikolom“Hikmah"adalahaspe kkohesinya.

Kekohesifanwacanadapatditentukanolehas pekgramatikal dan aspekleksikal. Aspekkohesigramatikalditandaidengankonj ungsi, subsitusi, elipsis, dan rujukanataureferensi. Aspekkohesileksikal antara lainreiterasi dan kolokasi.

Gunamendapatkanhasil yang maksimal dan mendalam, penelitianiniakandilakukan pada salahsatuaspekkohesigramatikalwacanayait udariaspekkonjungsi. Bertolak dari apa yang dikemukakan di atas, peneliti akan menganalisis kohesi gramatikal dalam kolom "Hikmah".

Sebagaisatuanbahasatertinggi di atas kalimat, wacanatidaksekadardikaji secara formal 
dalamhalhubunganantarkalimat,

tetapidifokuskan pada fungsi dan penggunaanbahasasebagaisaranakomunika

si.

Esensisebuahwacanadapatdipandangdarisis ikomunikasi dan darisisimaksudmaksudkomunikasiitusendiri (Achmad, 2006:3). Salah satu tujuan analisis wacana adalah mengamati kesatuan wacana itu.

Berdasarkansifat dan fungsinyadalamkomunikasi, wacanadapatbersifattransaksional dan interaksional. Bersifattransaksionalkarena yang

dipentingkanadalahunsurisikomunikasiitu. Bersifat transaksional karena merupakan komunikasi timbal balik (Brown, 1996: 2).

Dengan demikian, dalam analisis wacana tidak ditelaah satu kalimat saja atau satu paragraf saja, Akan tetapi keseluruhan teks, termasuk kaitan antara wacana tersebut dan konteksnya (Yuwono, 2005: 92). Itulah yang membedakan wacana sebagai pemakaian bahasa dalam komunikasi dengan pemakaian bahasa bukan untuk tujuan komunikasi.

Menurut Sumarlam (2003:138), kohesi adalah hubungan semantik atau hubungan makna antarunsur di dalam teks dan unsur-unsur lain yang penting untuk menafsirkan atau menginterpretasikan teks; pertautan logis antarkejadian atau maknamakna di dalamnya; keserasian hubungan antarunsur yang satu dengan yang lain dalam wacana sehingga terciptalah pengertian yang apik. Berkenaan dengan masalah kohesi, Halliday dan Hasan (1985: 67) membagi kohesi ke dalam lima jenis. Kelima jenis tersebut adalah (1) substitusi, yaitu penyulihan suatu kata atau kelompok kata oleh kata lain untuk tujuan tertentu; (2) referensi, yaitu hubungan pengacuan suatu unsur dengan unsur lain baik yang muncul sebelumnya, sesudahnya, atau bahkan di luar teks; (3) elipsis, yaitu pelesapan suatu kata atau bagian dari kalimat yang dilakukan untuk kepaduan wacana; (4) konjungsi; yaitu hubungan yang mengindikasikan bagaimana sebuah 
kalimat atau klausa dihubungkan dengan kalimat atau klausa lain; dan (5) kohesi leksikal, yaitu hubungan semantis antarunsur pembentuk wacana dengan memanfaatkan unsur leksikal atau kata. Dalam hal ini tidak menyangkut hubungan gramatikal tetapi hubungan tersebut didasari oleh makna kata yang digunakannya. Terdapat dua wujud kohesi leksikal, yaitu reiterasi dan kolokasi.

Berdasarkan uraian tersebut, dapat disimpulkan bahwa kohesi adalah hubungan perkaitan antarkalimat yang dinyatakan secara eksplisit (nyata) antara satu kalimat dengan kalimat lainnya atau unsur yang lebih besar yang membentuk wacana baik lisan maupun tulis yang membentuk keserasian sehingga terciptalah pengertian yang apik yang ditandai dengan adanya unsur gramatikal dan unsur leksikal.

Menurut Achmad (2006: 8), kohesi gramatikal adalah perpautan bentuk antara kalimat-kalimat yang diwujudkan dalam sistem gramatikal atau pemarkah gramatikal. Pemarkah gramatikal tersebut berupa unsur-unsur kaidah bahasa yang selanjutnya berfungsi sebagai alat penentu kohesi. Alat penentu kohesi tersebut berguna untuk menghubungkan ide antarkalimat.

Pendapat lain mengenai kohesi gramatikal dikemukakan oleh Yuwono. Menurut Yuwono (2005: 96), kohesi gramatikal adalah hubungan semantis antarunsur yang dimarkahi oleh alat gramatikal atau alat bahasa yang digunakan dalam kaitannya dengan tatabahasa.Konjungsi adalah pemarkah kohesi gramatikal yang menghubungkan kata dengan kata, frasa dengan frasa, atau klausa dengan klausa, dalam satu kalimat dan juga yang mengubungkan kalimat dengan kalimat dalam satu paragraf, atau menghubungkan paragraf dengan paragraf atau unsur yang lebih besar lagi sebagai bentuk ujaran baik yang setataran atau tidak dalam wacana yang meliputi empat tipe hubungan, yaitu aditif (penambahan), 
adversatif (pertentangan), kausal (sebabakibat), dan temporal (waktu).

\section{METODOLOGI PENELITIAN}

Metode yang digunakan dalam penelitian ini adalah metode kualitatif. Endraswara (2004:5) menyatakan bahwa "penelitian kualitatif adalah penelitian yang dilakukan dengan tidak mengutamakan angka-angka, tetapi mengutamakan kedalaman penghayatan terhadap interaksi antarkonsep yang sedang dikaji secara empiris". Metode penelitian bahasa berkaitan pula dengan tujuan penelitian serta melibatkan pengumpulan dan pemilihan data (Ratna, 2008: 66-68).Penelitian ini dilakukan di Jakarta, mulai dilakukan bulan Maret tahun 2016.Cara kerja penelitian ini adalah meneliti dan mendeskripsikan data tertulis berupa kolom "Hikmah" surat kabar Republika. Metode yang digunakan adalah studi dokumenter analisis isi.Fokus penelitian ini adalah pemarkah kohesi gramatikal yang berupa konjungsi antarkalimat.Objek penelitian ini adalah kumpulan kolom "Hikmah" surat kabar Republika periode Januari sampai dengan Desember 2015 sejumlah 286 terbitan (286 judul tulisan) dengan rincian:

\begin{tabular}{|c|l|c|}
\hline No & \multicolumn{1}{|c|}{ Bulan } & Jumlah Judul \\
\hline 1 & Januari & 23 \\
\hline 2 & Februari & 23 \\
\hline 3 & Maret & 24 \\
\hline 4 & April & 26 \\
\hline 5 & Mei & 24 \\
\hline 6 & Juni & 25 \\
\hline 7 & Juli & 25 \\
\hline 8 & Agustus & 25 \\
\hline 9 & September & 21 \\
\hline 10 & Oktober & 25 \\
\hline 11 & November & 20 \\
\hline 12 & Desember & 286 \\
\hline \multicolumn{1}{|c|}{ Jumlah } & \\
\hline
\end{tabular}

Dari hasil pengundian tiap terbitan, didapatkan data sampel secara rinci sebagai berikut: 


\begin{tabular}{|c|c|c|c|}
\hline $\begin{array}{c}\text { Tanggal } \\
\text { Terbit }\end{array}$ & Terbitan ke- & $\begin{array}{l}\text { Jumlah } \\
\text { Paragraf }\end{array}$ & $\begin{array}{c}\text { Paragraf } \\
\text { yang } \\
\text { Dianalisis }\end{array}$ \\
\hline $01 / 08 / 15$ & 1 & 4 & $1,2,4$ \\
\hline $02 / 08 / 15$ & tidak terbit (Minggu) & - & - \\
\hline $03 / 08 / 15$ & 2 & 10 & $4,7,8$ \\
\hline $04 / 08 / 15$ & 3 & 11 & $3,5,10$ \\
\hline $05 / 08 / 15$ & 4 & 9 & $2,8,9$ \\
\hline $06 / 08 / 15$ & 5 & 4 & $1,3,4$ \\
\hline $07 / 08 / 15$ & 6 & 10 & $1,6,8$ \\
\hline $08 / 08 / 15$ & 7 & 4 & $2,3,4$ \\
\hline $09 / 08 / 15$ & tidak terbit (Minggu) & - & - \\
\hline $10 / 08 / 15$ & 8 & 10 & $5,7,10$ \\
\hline $11 / 08 / 15$ & 9 & 8 & $5,7,8$ \\
\hline $12 / 08 / 15$ & 10 & 12 & $4,7,12$ \\
\hline $13 / 08 / 15$ & 11 & 7 & $4,5,6$ \\
\hline $14 / 08 / 15$ & 12 & 5 & $2,4,5$ \\
\hline $15 / 08 / 15$ & 13 & 5 & $2,3,5$ \\
\hline $16 / 08 / 15$ & tidak terbit (Minggu) & - & - \\
\hline $17 / 08 / 15$ & tidak terbit (HUT RI) & - & - \\
\hline $18 / 08 / 15$ & 14 & 7 & $1,4,5$ \\
\hline $19 / 08 / 15$ & 15 & 9 & $4,8,9$ \\
\hline $20 / 08 / 15$ & 16 & 10 & $3,6,8$ \\
\hline $21 / 08 / 15$ & 17 & 7 & $2,3,6$ \\
\hline $22 / 08 / 15$ & 18 & 6 & $1,3,5$ \\
\hline $23 / 08 / 15$ & tidak terbit (Minggu) & - & - \\
\hline $24 / 08 / 15$ & 19 & 8 & $4,5,6$ \\
\hline $25 / 08 / 15$ & 20 & 6 & $1,5,6$ \\
\hline $26 / 08 / 15$ & 21 & 8 & $1,6,7$ \\
\hline $27 / 08 / 15$ & 22 & 9 & $3,5,8$ \\
\hline $28 / 08 / 15$ & 23 & 10 & $1,6,8$ \\
\hline $29 / 08 / 15$ & 24 & 5 & $2,3,5$ \\
\hline $30 / 08 / 15$ & tidak terbit (Minggu) & - & - \\
\hline $31 / 08 / 15$ & 25 & 9 & $3,4,9$ \\
\hline Jumlah & 25 & 193 & 75 \\
\hline
\end{tabular}

Instrumen penelitian ini adalah peneliti sendiri dengan dibantu tabel analisis pemarkah kohesi gramatikal konjungsiantarkalimat berikut ini.

\begin{tabular}{|c|c|c|c|c|c|c|c|c|c|c|c|c|c|}
\hline \multirow{3}{*}{ No. } & \multirow{3}{*}{$\begin{array}{l}\text { No. } \\
\text { Psg. }\end{array}$} & \multicolumn{12}{|c|}{ Konjungsi Antarkalimat } \\
\hline & & \multicolumn{3}{|c|}{ Aditif } & \multicolumn{3}{|c|}{ Adversatif } & \multicolumn{3}{|c|}{ Kausal } & \multicolumn{3}{|c|}{ Temporal } \\
\hline & & $\begin{array}{l}\text { Ada } \\
(+)\end{array}$ & $\begin{array}{c}\text { Konju } \\
\text { ngsi }\end{array}$ & Tpt & $\begin{array}{l}\text { Ada } \\
(+)\end{array}$ & $\begin{array}{l}\text { Konj } \\
\text { ungsi }\end{array}$ & Tpt & $\begin{array}{c}\text { Ada } \\
(+)\end{array}$ & $\begin{array}{c}\text { Konju } \\
\text { ngsi }\end{array}$ & Tpt & $\begin{array}{c}\text { Ada } \\
(+)\end{array}$ & $\begin{array}{c}\text { Konju } \\
\text { ngsi }\end{array}$ & $\mathrm{Tpt}$ \\
\hline
\end{tabular}




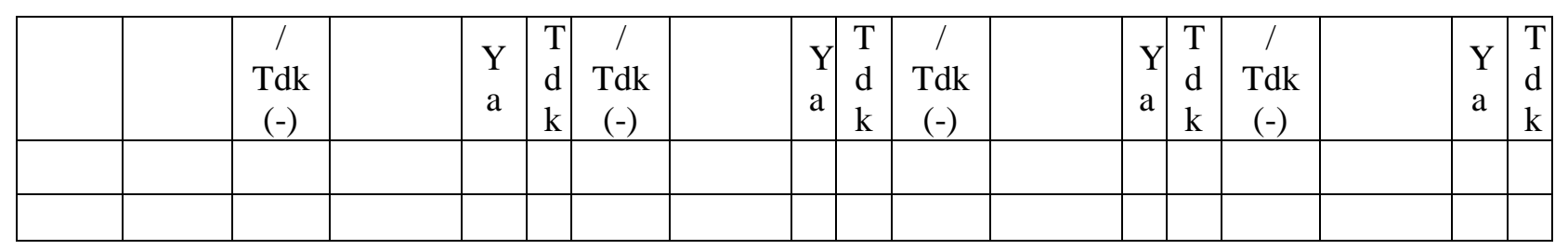

Contoh cara meneliti kohesi gramatikal konjungsi dalam penelitian ini adalah sebagai berikut:

\section{Menentukan data berupa teks}

Dewasa ini, saat harga-harga kebutuhan pokok melambung tinggi, berat rasanya beban yang harus ditanggung rakyat kecil. Akibatnya, untuk tetap bertahan hidup, tidak sedikit dari mereka yang terpaksa gali lubang tutup lubang, meminjam uang dari sana dan membayar utang dari sini. Berutang sah-sah saja, selama hal itu dimaksudkan untuk memenuhi kebutuhan pokok. Akan tetapi, berutang dapat menjadi sesuatu yang tercela ketika ia dilakukan untuk bermewah-mewahan.

\section{Dekontekstualisasi}

(Pelepasan

\section{kalimat dari paragraf)}

(1) Dewasa ini, saat harga-harga kebutuhan pokok melambung tinggi, berat rasanya beban yang harus ditanggung rakyat kecil.

(2) Akibatnya, untuk tetap bertahan hidup, tidak sedikit dari mereka yang terpaksa gali lubang tutup lubang, meminjam uang dari sana dan membayar utang dari sini.

(3) Berutang sah-sah saja, selama hal itu dimaksudkan untuk memenuhi kebutuhan pokok.

(4) Akan tetapi, berutang dapat menjadi sesuatu yang tercela ketika ia dilakukan untuk bermewahmewahan.

\section{Menentukan}

pasangan berdekatan

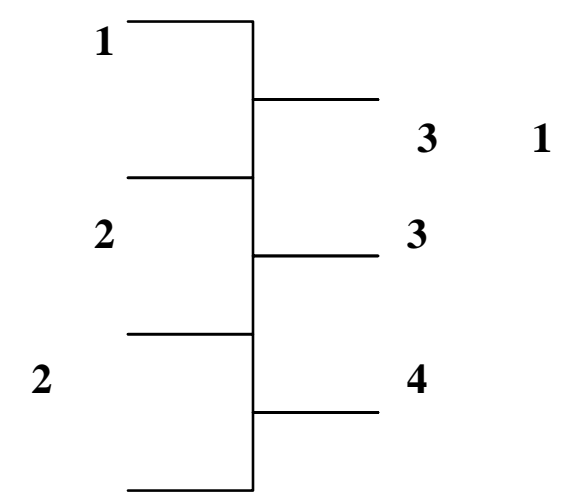


4. Menuliskan

pasangan-pasangan

berdekatan

Pasangan 1

(1) Dewasa ini, saat harga-harga kebutuhan pokok melambung tinggi, berat rasanya beban yang harus ditanggung rakyat kecil.

(2) Akibatnya, untuk tetap bertahan hidup, tidak sedikit dari mereka yang terpaksa gali lubang tutup lubang, meminjam uang dari sana dan membayar utang dari sini.

\section{Pasangan 2}

(2) Akibatnya, untuk tetap bertahan hidup, tidak sedikit dari mereka yang terpaksa gali lubang tutup lubang, meminjam uang dari sana dan membayar utang dari sini.

(3) Berutang sah-sah saja, selama hal itu dimaksudkan untuk memenuhi kebutuhan pokok.

\section{Pasangan 3}

(3) Berutang sah-sah saja, selama hal itu dimaksudkan untuk memenuhi kebutuhan pokok.

(4) Akan tetapi, berutang dapat menjadi sesuatu yang tercela ketika ia dilakukan untuk bermewah-mewahan.

\section{Melakukan analisis}

$\underline{\text { Pasangan } 1}$

a. Data

(1) Dewasa ini, saat harga-harga kebutuhan pokok melambung tinggi, berat rasanya beban yang harus ditanggung rakyat kecil.

(2) Akibatnya, untuk tetap bertahan hidup, tidak sedikit dari mereka yang terpaksa gali lubang tutup lubang, meminjam uang dari sana dan membayar utang dari sini.

b. Analisis

- Kalimat (2) menggunakan konjungsi antarkalimat akibatnya untuk menghubungkan dengan kalimat (1), menyatakan konjungsi hubungan kausal

c. Kesimpulan 
Jadi, kalimat (2) dan (1) membentuk kohesi gramatikal dengan konjungsi antarkalimat akibatnya, yang menyatakan hubungan kausal atau sebab akibat.

\section{Pasangan 2}

a. Data

(2) Akibatnya, untuk tetap bertahan hidup, tidak sedikit dari mereka yang terpaksa gali lubang tutup lubang, meminjam uang dari sana dan membayar utang dari sini.

(3) Berutang sah-sah saja, selama hal itu dimaksudkan untuk memenuhi kebutuhan pokok.

b. Analisis

- Kalimat (3) tidak menggunakan konjungsi untuk menghubungkan dengan kalimat (2). c. Kesimpulan

Jadi, kalimat (3) dan (2) membentuk kohesi gramatikal tidak dengan pemarkah.

\section{HASIL DAN PEMBAHASAN}

Deskripsi data dimaksudkan untuk memberikan gambaran tentang data yang diteliti.Sumber data penelitian ini adalah wacana kolom "Hikmah" harian umum Republika yang terbit tahun 2015. Wacana tersebut terdiri atas 286 judul yang terbit dari bulan Januari hingga Desember 2015. Selanjutnya, ke-286 judul tersebut diundi untuk menentukan data yang akan dianalisis dengan cara berikut ini. Pertama, data tersebut dikelompokkan ke dalam dua kelompok, yaitu enam bulan pertama (Januari-Juni) dan enam bulan kedua (Juli-Desember), kemudian dilakukan pengundian. Dari hasil pengundian diperoleh data enam bulan kedua yaitu Juli-Desember. Kedua, data enam bulan kedua tersebut dikelompokkan lagi menjadi dua, yaitu kelompok tiga bulan pertama (Juli-September) dan kelompok 
tiga bulan kedua (Oktober-Desember), kemudian dilakukan pengundian dan diperoleh hasil tiga bulan pertama (JuliSeptember). Ketiga, data tiga bulan pertama tersebut selanjutnya diundi untuk menentukan data satu bulan yang akan dianalisis. Dari pengundian yang dilakukan, diperoleh data bulan Agustus. Jadi, data yang akan dianalisis adalah wacana kolom "Hikmah" yang terbit bulan
Agustus 2016, yang terdiri atas dua puluh lima judul.

Dari ke-25 judul wacana tersebut, dilakukan penghitungan jumlah paragraf tiap judul dengan mengecualikan paragraf yang berisi kutipan terjemah ayat Alquran dan hadist, kemudian dilanjutkan dengan pengundian untuk menentukan tiga paragraf tiap judul yang akan dianalisis, dengan hasil seperti yang terdapat pada Tabel 1 berikut ini;

Tabel 1: Sumber Data Penelitian

\begin{tabular}{|c|c|l|c|c|}
\hline \multirow{2}{*}{ No } & \multirow{2}{*}{$\begin{array}{c}\text { Terbit } \\
\text { ke- }\end{array}$} & \multicolumn{1}{|c|}{ Judul } & \multicolumn{2}{|c|}{ Paragraf } \\
\cline { 3 - 5 } & & & Jumlah & $\begin{array}{c}\text { Yang } \\
\text { Dianalisis }\end{array}$ \\
\hline 1 & 1 & Haji dan Pendidikan Ekologi & 4 & $1,2,4$ \\
\hline 2 & 2 & Menjadi Tamu Allah & 10 & $4,7,8$ \\
\hline 3 & 3 & Tingkatan Cobaan di Dunia & 11 & $3,5,10$ \\
\hline 4 & 4 & Etika Tamu Allah & 9 & $2,8,9$ \\
\hline 5 & 5 & Berserah Diri kepada Allah & 4 & $1,3,4$ \\
\hline 6 & 6 & Mendoakan Jamaah Haji & 10 & $1,6,8$ \\
\hline 7 & 7 & Haji adalah Peluang & 4 & $2,3,4$ \\
\hline 8 & 8 & Kemerdekaan yang Sesungguhnya & 10 & $5,7,10$ \\
\hline 9 & 9 & Berbekal Pergi Haji & 8 & $5,7,8$ \\
\hline 10 & 10 & Kemerdekaan Sejati Manusia & 12 & $4,7,12$ \\
\hline 11 & 11 & Ini 6 Keistimewaan Universitas & 7 & $4,5,6$ \\
\hline 12 & 12 & Etika Tamu Allah & 5 & $2,4,5$ \\
\hline 13 & 13 & Penghalang Keberkahan Nikmat & 5 & $2,3,5$ \\
\hline 14 & 14 & Urgensi Pemahaman & 7 & $1,4,5$ \\
\hline 15 & 15 & Prinsip Kemerdekaan & 9 & $4,8,9$ \\
\hline 16 & 16 & Semua Milik Allah & 10 & $3,6,8$ \\
\hline 17 & 17 & Puasa Membentuk Manusia Baru & 7 & $2,3,6$ \\
\hline 18 & 18 & Kenikmatan Spiritual & 6 & $1,3,5$ \\
\hline 19 & 19 & Kekuatan Moral & 8 & $4,5,6$ \\
\hline 20 & 20 & Pidato Kenegaraan & 6 & $1,5,6$ \\
\hline
\end{tabular}




\begin{tabular}{|c|c|l|c|c|}
21 & 21 & Berbisnis dengan Allah & 8 & $1,6,7$ \\
\hline 22 & 22 & Sederhana Itu Indah & 9 & $3,5,6$ \\
\hline 23 & 23 & Rezeki & 10 & $1,6,8$ \\
\hline 24 & 24 & Ditinggalkan Oleh Waktu & 5 & $2,3,5$ \\
\hline 25 & 25 & Indahnya Berbeda & 9 & $3,4,9$ \\
\hline \multicolumn{2}{|c|}{ Jumlah } & 25 & 193 & 75 \\
\hline
\end{tabular}

Dalam analisis data, wacana kolom

"Hikmah" harian umum Republika yang terbit bulan Agustus 2015 yang terdiri atas 25 judul ini selanjutnya akan dianalisis tiap judul. Analisis tiap judul ini dilakukan untuk menemukan konjungsi antarkalimat, jenis hubungan konjungsi yang ditemukan menyatakan aditif, adversatif, kausal, ataukah temporal dan ketepatan penggunaan konjungsi antarkalimat tersebut. Berdasarkan rekapitulasi hasil penelitian, diketahui bahwa dari 124 pasangan kalimat, 80 pasangan berdekatan atau $64,5 \%$ tidak menggunakan konjungsi sebagai pembentuk kohesi gramatikal. Namun demikian, bukan berarti pasangan berdekatan tersebut tidak kohesif secara gramatikal, mengingat masih terdapat tiga faktor lain yang menjadi pembentuk kohesi gramatikal selain konjungsi, yaitu referensi (pengacuan), substitusi (penyulihan), dan elipsis (pelepasan). Untuk itu, perlu dilakukan penelitian lebih lanjut untuk mengetahui penggunaan ketiga pembetuk kohesi gramatikal tersebut pada kesempatan lain, karena ketiga pembentuk kohesi gramatikal tersebut tidak menjadi bagian dalam penelitian ini.

Sementara itu, terdapat 44 pasangan berdekatan atau sebesar 35,5\% menggunakan konjungsi antarkalimat sebagai pembentuk kohesi gramatikal. Jumlah ini cukup signifikan, karena dari empat unsur pembentuk kohesi gramatikal (referensi, substitusi, elipsis, dan konjungsi) jumlah pasangan berdekatan yang menggunakan telah melebihi $25 \%$.

$$
\text { Ke-44 pasangan berdekatan }
$$
tersebut, yang frekeunsi penggunaanya tertinggi adalah konjungsi aditif (menyatakan hubungan penambahan atau penjumlahan). Konjungsi ini ditemukan pada enam belas pasangan berdekatan atau 
sebesar $12,9 \%$ yang tersebar pada tiga belas judul wacana kolom "Hikmah" dari 25 judul yang dianalisis. Frekuensi penggunaan konjungsi terbanyak urutan kedua adalah konjungsi adversatif (menyatakan hubungan pertentangan) yang ditemukan pada sepuluh pasangan berdekatan atau sebesar $8,1 \%$, tersebar pada delapan judul wacana kolom "Hikmah".

Selanjutnya, penggunaan konjungsi dengan frekuensi urutan ketiga ditemukan pada dua jenis konjungsi. Kedua jenis konjungsi tersebut yaitu konjungsi kausal (menyatakan hubungan sebab akibat) dan konjungsi temporal (menyatakan hubungan waktu) masing-masing ditemukan pada sembilan pasangan berdekatan yang berbeda atau masing-masing sebesar 7,3 $\%$. Sembilan pasangan berdekatan yang menggunakan konjungsi kausal tersebar pada delapan judul wacana, sedangkan sembilan pasangan dengan konjungsi temporal tersebar pada lima judul.
Berdasarkan ketepatan penggunaan konjungsi, dari 44 pasangan berdekatan yang menggunakan konjungsi antarkalimat sebagai pembentuk kohesi gramatikal, ditemukan 38 pasang atau sebesar $86,4 \%$ menggunakan konjungsi dengan tepat dan 6 pasang atau sebesar 13,6 \% menggunakan konjungsi secara tidak tepat. Enam pasang dengan konjungsi yang tidak tepat tersebut, terdiri atas 4 pasang atau sebesar 9,1 \% menggunakan konjungsi yang menyatakan hubungan aditif dan 2 pasang atau sebesar 4,5\% menggunakan konjungsi yang menyatakan hubungan kausal.

Empat pasangan berdekatan dengan penggunaan konjungsi aditif yang tidak tepat tersebut, tiga pasang mempunyai kasus yang sama, yaitu menggunakan konjungsi “dan" sebagai penghubung antarkalimat dan satu pasang menggunakan partikel "pun" yang difungsikan sama dengan konjungsi “juga". Tiga pasangan berdekatan yang menggunakan konjungsi "dan" tersebut 
yaitu terdapat pada judul ke-3 paragraf 5 pasangan 1, judul ke-16 paragraf 8 pasangan 1, dan judul ke-25 paragraf 9 pasangan 1. Berikutnya, satu pasangan berdekatan yang menggunakan partikel "pun” yang difungsikan sebagai konjungsi “juga” terdapat pada judul ke-5 paragraf 1 pasangan 4.

Selanjutnya, dua pasangan berdekatan dengan penggunaan konjungsi kausal yang tidak tepat terdapat pada judul ke-11 paragraf 6 pasangan 2 dan judul ke15 paragraf 9 pasangan 1 . Kedua pasangan berdekatan ini menggunakan konjungsi intrakalimat "karena".

Dengan demikian, ketidaktepatan penggunaan konjungsi pada enam pasangan berdekatan wacana kolom "Hikmah" pada dasarnya terdiri atas tiga macam konjungsi, yaitu konjungsi “dan”, partikel "pun" sebagai konjungsi "juga" dan konjungsi "karena". Berdasarkan kaidah penggunaan konjungsi dan kategori konjungsi dalam penelitian ini, kedua jenis konjungsi tersebut bukan termasuk dalam kelompok konjungsi antarkalimat, melainkan kelompok konjungsi intrakalimat. Penggunaan kedua macam konjungsi tersebut untuk menguhungkan kalimat satu dengan lainnya merupakan penggunaan yang tidak tepat.

Kesalahan partikel "pun” pada judul ke-5 paragraf 1 pasangan 4 terjadi karena kesalahan struktur kedua kalimat pada pasangan berdekatan tersebut. Kalimat 5 dan kalimat 5 sebenarnya merupakan kalimat yang salah. Kalimat 4 merupakan klausa terikat dengan konjungsi temporal intrakalimat "sementara" yang tidak bisa dipisahkan dengan kalimat 5 yang merupakan klausa bebas. Penggunaan partikel "pun" dalam konteks ini harusnya dipasangkan dengan konjungsi "sementara" sehingga menjadi 'sementara ... pun .... .

Temuan lain berdasarkan analisis data adalah adanya penggunaan partikel "pun” yang difungsikan sebagai konjungsi antarkalimat. Namun, partikel "pun “ dalam kasus ini digunakan secara tepat, 
tidak seperti penggunaan "pun” pada kasus yang telah dibahas sebelumnya, yang difungsikan sebagai konjugsi intrakalimat. Partikel "pun" tersebut difungsikan sebagai konjungsi antarkalimat. Hal ini ditemukan pada tiga pasangan berdekatan, yaitu pada judul ke-5 paragraf 3 pasangan 3, judul ke18 paragraf 5 pasangan 3 , dan pada judul ke-24 paragraf 2 pasangan 3.

Temuan lain berikutnya adalah mengenai bentuk tulisan wacana kolom "Hikmah" secara umum, yaitu pengembangan paragraf. Dari 75 paragraf wacana kolom "Hikmah" diteliti, sejumlah 46 paragraf atau sebesar $61,33 \%$ terdiri atas dua kalimat (satu pasangan berdekatan). Berdasarkan kriteria paragraf yang baik, paragraf tersebut termasuk paragraf yang tidak baik pengembangannya.

\section{SIMPULAN}

Berdasarkan Rekapitulasi Hasil Penelitian tentang kohesi gramatikal konjungsi wacana kolom "Hikmah" surat kabar Republika, diketahui bahwa dari 124 pasangan kalimat dari 75 paragraf yang diambil dari 25 judul kolom melalui undian, 80 pasangan berdekatan atau 64,5 \% tidak menggunakan konjungsi sebagai pembentuk kohesi gramatikal. Sementara itu, terdapat 44 pasangan berdekatan atau sebesar 35,5\% menggunakan konjungsi antarkalimat sebagai pembentuk kohesi gramatikal.

\section{Konjungsi-konjungsi}

yang digunakan dalam 44 pasangan berdekatan tersebut tersebar dalam empat kategori hubungan, yaitu:

1. Konjungsi aditif (Hubungan penambahan)

Konjungsi aditif yang digunakan sejumlah sembilan konjungsi antara lain bahkan, pun, tak terkecuali, apa pun, dan, demikian halnya, apalagi, begitupun, dan pula. Konjungsi ini ditemukan pada enam belas pasangan berdekatan atau sebesar $12,9 \%$ yang tersebar pada tiga belas judul wacana kolom "Hikmah" dari 25 judul yang dianalisis. 
2. Konjungsi adversatif (Hubungan pertentangan)

Konjungsi adversatif yang digunakan sejumlah tujuh konjungsi antara lain tapi, padahal, hanya saja, hanya, meski, sebaliknya, dan tetapi. Konjungsi ini ditemukan pada sepuluh pasangan berdekatan atau sebesar $8,1 \%$, tersebar pada delapan judul wacana kolom "Hikmah".

3. Konjungsi Kausal (Hubungan sebab akibat)

Konjungsi kausal yang digunakan sejumlah tujuh konjungsi antara lain jadi, memang, karenanya, karena, karena itu, tentu, dan sesungguhnya. Konjungsi ini ditemukan pada sembilan pasangan berdekatan atau sebesar $7,3 \%$, tersebar pada delapan judul wacana, sedangkan sembilan pasangan dengan konjungsi temporal tersebar pada lima judul.

4. Konjungsi Temporal (Hubungan waktu)
Konjungsi temporal yang digunakan sejumlah sembilan konjungsi antara lain suatu hari, sementara, pada saat itu, setiap kali, dahulu pada masa, lalu, tatkala, kini, dan pada akhirnya. Konjungsi ini ditemukan pada sembilan pasangan berdekatan atau sebesar $7,3 \%$, tersebar pada lima judul wacana.

Berdasarkan ketepatan penggunaan konjungsi, ditemukan 38 pasang atau sebesar $86,4 \%$ menggunakan konjungsi dengan tepat dan 6 pasang atau sebesar 13,6 \% menggunakan konjungsi secara tidak tepat. Enam pasang dengan konjungsi yang tidak tepat tersebut, terdiri atas 4 pasang atau sebesar 9,1\% menggunakan konjungsi yang menyatakan hubungan aditif dan 2 pasang atau sebesar 4,5\% menggunakan konjungsi yang menyatakan hubungan kausal.

Mengenai bentuk tulisan wacana kolom "Hikmah" secara umum, yaitu pengembangan paragraf, dari 75 paragraf wacana kolom "Hikmah" diteliti, sejumlah 46 paragraf atau sebesar $61,33 \%$ 
dikembangkan dengan cara yang tidak

baik. Sejumlah 29 paragraf atau sebesar

$38,67 \%$ telah dikembangkan dengan baik.

\section{UCAPAN TERIMA KASIH}

Peneliti mengucapkan terima kasih kepada berbagai pihak yang telah membantu dalam proses penelitian ini.

\section{DAFTAR RUJUKAN}

Brown, G, \& Yule, G. (1996). Discourse Analysis. Sydney: Cambridge University Press.

Endraswara, Suwardi. (2004). Metodologi Penelitian Sastra: Epistemologi, Model, Teori, dan Aplikasi. Yogyakarta: Pustaka Widyatama.

Halliday, M.A.K. and Ruqaiya Hasan (1985). Language. Context And Text: Aspects of Language In A Social-Semiotic Perspective.Oxford: Oxford University Press.

H.P., Achmad. (2006).Aspek Kohesi Wacana. Jakarta: Fakultas Bahasa dan Seni Universitas Negeri Jakarta.

Ratna, N.K. (2008). Teori, Metode, dan Teknik Penelitian Sastra. Yogyakarta: Pustaka Pelajar.

Sumarlam.(2003). Teori dan Praktik Analisis Wacana. Surakarta: Pustaka Cakra.
Yuwono, Untung. (2005). Pesona Bahasa: Langkah Awal Memahami Linguistik. Jakarta: Gramedia Pustaka Utama.

\section{Surat Kabar:}

Republika, Jakarta, 1 Agustus 2015 Republika, Jakarta, 3 Agustus 2015

Republika, Jakarta, 4 Agustus 2015

Republika, Jakarta, 5 Agustus 2015

Republika, Jakarta, 6 Agustus 2015

Republika, Jakarta, 7 Agustus 2015

Republika, Jakarta, 8 Agustus 2015

Republika, Jakarta, 10 Agustus 2015

Republika, Jakarta, 11 Agustus 2015

Republika, Jakarta, 12 Agustus 2015

Republika, Jakarta, 13 Agustus 2015

Republika, Jakarta, 14 Agustus 2015

Republika, Jakarta, 15 Agustus 2015

Republika, Jakarta, 18 Agustus 2015

Republika, Jakarta, 19 Agustus 2015

Republika, Jakarta, 20 Agustus 2015

Republika, Jakarta, 21 Agustus 2015

Republika, Jakarta, 22 Agustus 2015

Republika, Jakarta, 24 Agustus 2015

Republika, Jakarta, 25 Agustus 2015

Republika, Jakarta, 26 Agustus 2015

Republika, Jakarta, 27 Agustus 2015

Republika, Jakarta, 28 Agustus 2015

Republika, Jakarta, 29 Agustus 2015 
Republika, Jakarta, 31 Agustus 2015 